\title{
High activity of horizontal gene transfer in nodule bacteria as a strategy for interaction with legumes
}

Baymiev An.Kh., Vladimirova A.A., Akimova E.S., Koryakov I.S., Baymiev Al.Kh.

Institute of Biochemistry and Genetics - Subdivision of the Ufa Federal Research Centre of the Russian Academy of Sciences,

Ufa, Russia.

E-mail:baymiev@anrb.ru

Key message. The contribution of the legume plant to the formation of the genetic diversity of nodule bacteria and its effect on the activity of horizontal transfer of symbiotic genes in rhizospheric bacteria is studied.

Keywords: rhizobia, horizontal gene transfer, symbiotic genes, legumes

The interaction of partners in legume-rhizobium symbiosis occurs along a complex multi-stage path in which both plant and bacterial components take an active part. Leguminous plants of a temperate climate, mostly perennial, undergo multiple cycles of interaction with nodule bacteria during their ontogenesis. An important role in this is played by seasonal cyclicality, in which cycles of nodule formation and dying off occur. In turn, nodule bacteria undergo changes in ecological niches in the plant-soil system in which various selection factors act on bacteria. The main genetic component in the legume-rhizobial interaction is the symbiotic bacterial genes, which largely determine the specificity and effectiveness of legume-rhizobial symbiosis. In the saprophytic state, rhizobia often lead to the loss of symbiotic genes as unnecessary genetic material under the given conditions of existence. The continuous processes of loss and acquisition of sym genes associated with "infection and release" require nodule bacteria to have genome plasticity and high horizontal gene transfer activity, which, in turn, is one of the reasons for the high polymorphism of the populations of these microorganisms. The contribution of the legume plant to the formation of the genetic diversity of nodule bacteria, it's influence on the activity of horizontal transfer of symbiotic genes in rhizosphere bacteria by studying the patterns of changes in the genetic diversity and phylogenetic composition of nodule bacteria obtained from nodules of perennial wild legume plants at different stages of their ontogenesis, is considered. The mechanism for the formation of the specificity of legume-rhizobial symbiosis with high polymorphism of nodule bacteria, the importance of high mobility of symbiotic genes and the panmictic structure of the rhizobia population for successful symbiotic interaction are also considered.

\section{Высокая активность горизонтального переноса генов у клубеньковых бактерий как стратегия взаимодействия с бобовыми растениями \\ Баймиев Ан.Х., Владимирова А.А., Акимова Е.С., Коряков И.С., Баймиев Ал.Х.}

Институт биохимии и генетики - обособленное структурное подразделение Федерального государственного бюджетного научного учреждения Уфимского федерального исследовательского центра Российской академии наук, Уфа, Россия.

Аннотация. Рассмотрен вклад бобового растения в формирование генетического разнообразия клубеньковых бактерий, его влияния на активность горизонтального переноса симбиотических генов у ризосферных бактерий. Ключевые слова: ризобии, горизонтальный перенос генов, симбиотические гены, бобовые растения

Взаимодействие партнеров в бобово-ризобиальном симбиозе происходит по сложному многостадийному пути, в котором активное участие принимают как растительные, так и бактериальные компоненты. Бобовые растения, в большей степени умеренного климата, в ходе своего развития проходят многократные циклы взаимодействия с клубеньковыми бактериями. Немаловажную роль в этом играет сезонная цикличность, при котором происходят циклы образования и отмирания клубеньков. В свою очередь у клубеньковых бактерий при этом происходят изменения экологических ниш в системе «растение-почва», в которых на бактерии действуют различные факторы отбора. Основным генетическим компонентом в бобово-ризобиальном взаимодействии являются симбиотические гены бактерий, которые определяют во многом специфичность и эффективность бобово-ризобиального симбиоза. В сапрофитном состоянии у ризобий часто происходит потеря симбиотических генов, как ненужного генетического материала в данных условиях существования. Постоянные процессы потери и приобретения sут-генов, сопряженные с «инфекцией и освобождением», требуют от клубеньковых бактерий пластичности генома и высокой активности горизонтального переноса генов, что, в свою очередь, является одной из причин высокого полиморфизма популяций данных микроорганизмов. Рассмотрен вклад бобового растения в формирование генетического разнообразия клубеньковых бактерий, его влияния на активность горизонтального переноса симбиотических генов у ризосферных бактерий путем изучения закономерностей изменения генетического разнообразия и филогенетического состава клубеньковых бактерий, полученных из клубеньков многолетних дикорастущих бобовых растений на разных стадиях их онтогенеза, а также механизм формирования специфичности бобово-ризобиального симбиоза при высокой полиморфности клубеньковых бактерий, значении высокой мобильности симбиотических генов и панмиктичной структуры популяции ризобий для успешного симбиотического взаимодействия. 